\title{
Nodular hyperplasia of Bartholin's gland: case reports and literature review
}

\section{Hiperplasia nodular da glândula de Bartholin: relato de casos e revisão da literatura}

Raquel Wal'; Maurício Lirani Antonello²

\begin{tabular}{l|l}
\multicolumn{1}{c|}{ key words } & abstract \\
\hline Bartholin's gland & $\begin{array}{l}\text { The Bartholin's gland (BG) may develop several tumoral lesions such as BG duct cysts, carcinomas, } \\
\text { hyperplasias, and adenomas. BG nodular hyperplasias (NHs) are uncommon, and few cases have been } \\
\text { Nodular hyperplasia } \\
\text { reported in the literature. Specific criteria for the distinction between adenomas and hyperplasias have } \\
\text { been recently established. Several questions on possible etiologies and appropriate medical approach } \\
\text { still remain. Therefore, this work comprises three case reports of NH and an extensive literature review. }\end{array}$ \\
Vestibular glands &
\end{tabular}

\section{resumo}

A glândula de Bartholin (GB) pode ser sede de várias lesões tumorais, como cistos do ducto da GB, carcinomas, hiperplasias e adenomas. A hiperplasia nodular $(H N)$ da GB é uma lesão rara e poucos casos foram relatados na literatura. Recentemente, critérios específicos estabeleceram a diferenciação entre adenomas e hiperplasias. Muitas dúvidas ainda permanecem sobre as possíveis etiologias e a conduta ideal ante essa lesão. Diante disso, o presente trabalho realizou o relato de três casos de HN e ampla revisão sobre o tema. unitermos

Glândula de Bartholin

Hiperplasia nodular

Adenoma

Glândula vestibular

1. Master's degree on Celular biology; pathologist of the Department of Pathology, Hospital de Clínicas of Universidade Federal do Paraná (HC-UFPR); adjunt professor of Anatomical Pathology of Faculdade Evangélica do Paraná (FEPAR).

2. Medical student of FEPAR. 


\section{Introduction}

The feminine anogenital region contains many glands that can be home of benign or malignant tumors: the Bartholin's glands (BGs) - also known as major vestibular glands - and the Skene's paraurethral glands (also named minor vestibular glands). The BG is the most important gland of the vulva. Inflammatory process and duct cysts are by far the most frequent lesions in this location and carcinomas are the most prevalent solid tumors. Between the rare benign tumors, nodular hyperplasia $(\mathrm{NH})$ of $\mathrm{BC}$ appears to be the most common lesion ${ }^{(6,13)}$.

In 1997, the first case report of a NH of BG was published by Argenta et al.(1). One year later, specific diagnostic criteria were proposed by Koenig and Tavassoli ${ }^{(7)}$. Few cases have been reported on literature ${ }^{(1,3,5-7,13,14)}$.Therefore, we describe three cases of $\mathrm{NHs}$ with emphasis on the pathologic findings, differential diagnosis and possible etiologies based on our literature review.

\section{Case reports}

\section{Case 1}

A 35 year-old female presented with a complaint of a hardened nodule in her right labium without local inflammatory signs. The region was permanently swollen and she had pain during sexual intercourse. She also complained about a nonspecific pelvic pain that has begun a year ago. She denied unusual discharge, urinary or gastrointestinal complaints. Previously, she had annual episodes of BG's abscess. The patient underwent marsupialization. During the procedure, the glands were palpated, and bilateral solid lesions were found. The BGs were therefore completely excised. Examination revealed bilateral $3 \times 3 \times$ $3 \mathrm{~cm}$, tan, elastic nodules whose contours were irregular.

\section{Case 2}

A 45 year-old female presented with a painless $2 \mathrm{~cm}$ diameter fibrous nodule in the right labium. The lesion was discovered at random during colpoperineoplasty and it was surgical removed. The surgical specimen revealed a hardened $2 \times 1.5 \times 1.5 \mathrm{~cm}$, tan mass.

\section{Case 3}

A 38 year-old female presented with a left-sided swelling of the vulva. The gynecologist detected the painless nodule and it was resected. The patient reported that a similar lesion was excised 3 years ago. However, this one didn't undergo anatomicopathological examination because her previous gynecologist guaranteed that it was just a cyst. The surgical specimen, measuring $2.5 \times 1.5 \times 1 \mathrm{~cm}$, was tan-white in color, firm and elastic granular tumor.

\section{Results}

Our three lesions were formed by proliferated acini surrounding ducts. These lesions presented with nonencapsulated irregular borders (Figure 1). The gland's lobular architecture was preserved in all three cases (Figure 2). The ducts were lined by simple columnar epithelium, transitional epithelium or squamous metaplasia, without atypia (Figure 3). Surrounding the ducts, there were numerous acini constituted by mucin-containing cuboidal to columnar cells. The acinar cells' cytoplasms were clear and their nucleuses were basally sited (Figure 4). Necrosis and mitotic activity were absent. The stroma was fibrous. The peripheral tissue was compound by intensely vascularized fibrous tissue and striated muscle fibers. Some nervous fibers were seen near blood vessels and muscle fibers (Figure 5). In case 2, ruptured ducts and extravasated mucin were found. Some histiocytes whose cytoplasms were filled with mucin were visualized in this specimen.

\section{Discussion}

According to Koenig and Tavassoli, the term hyperplasia must be used if the lesion demonstrates preserved ductal/ acinar ratio, lobulation, irregular margin and absence of encapsulation. On the other hand, a mass must be classified as adenoma if it presents disrupted ductal/acinar architecture; diffuse or disorganized acinar and ductal proliferation; encapsulation or circumscribed $\operatorname{margin}^{(7)}$. This proposition was accepted by the majority of the recent authors $(1,3,5,7,13,14)$. Despite the fact that their cases were compatible with criteria for $\mathrm{NH}$, Kazakov et al. questioned if their lesions were just simple hyperplasia. Their specimens showed expansive growth, great size and complex histological appearance. Furthermore, they found monoclonal pattern in one of their two cases. This finding is a usual characteristic of neoplasias, but, it can also be found on some healthy tissues ${ }^{(6,7)}$.

The greatest part of the articles reporting adenomas were published before this criteria. Thus many crucial 


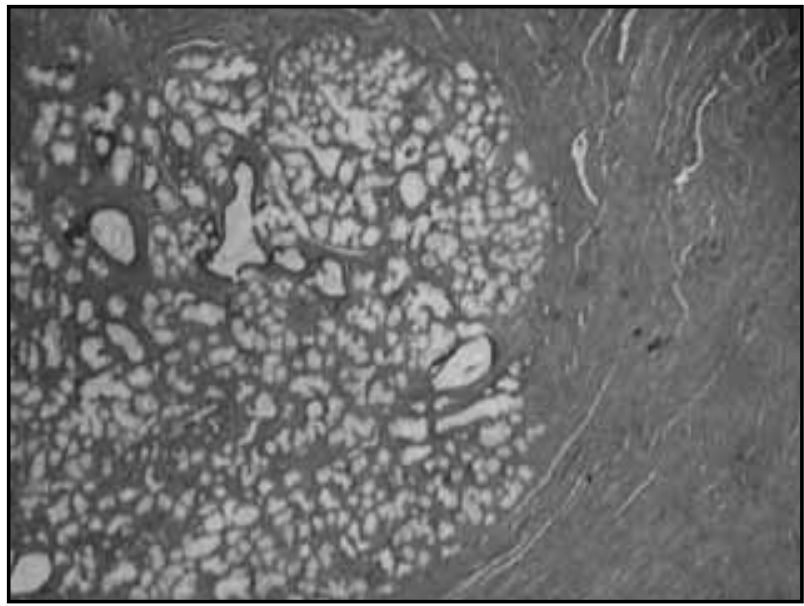

Figure 1 - Nodular hyperplasia's margin showing nonencapsuled and slightly irregular contour ( $H E$, magnification 40x)

HE: hematoxylin and eosin.

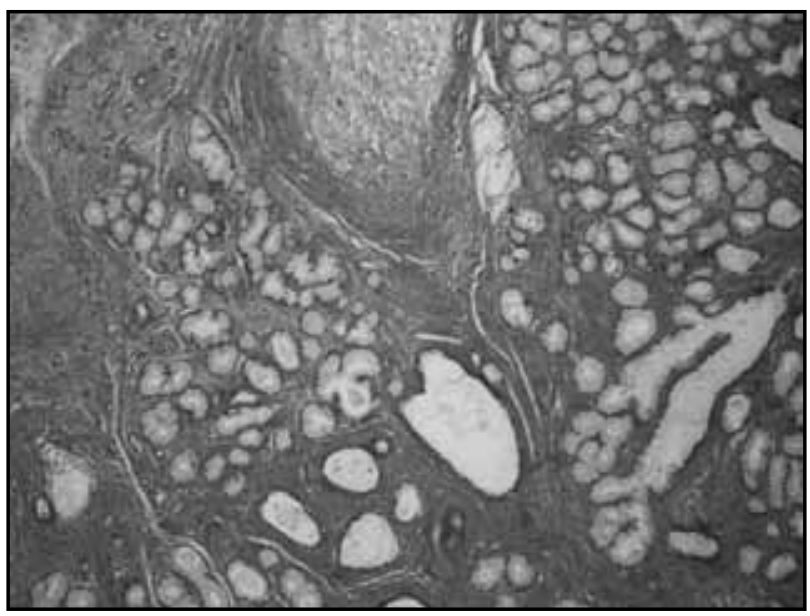

Figure 2 - Proliferation of acini in a lobular pattern draining to excretory ducts (HE, magnification 40x)

$H E$ : hematoxylin and eosin.

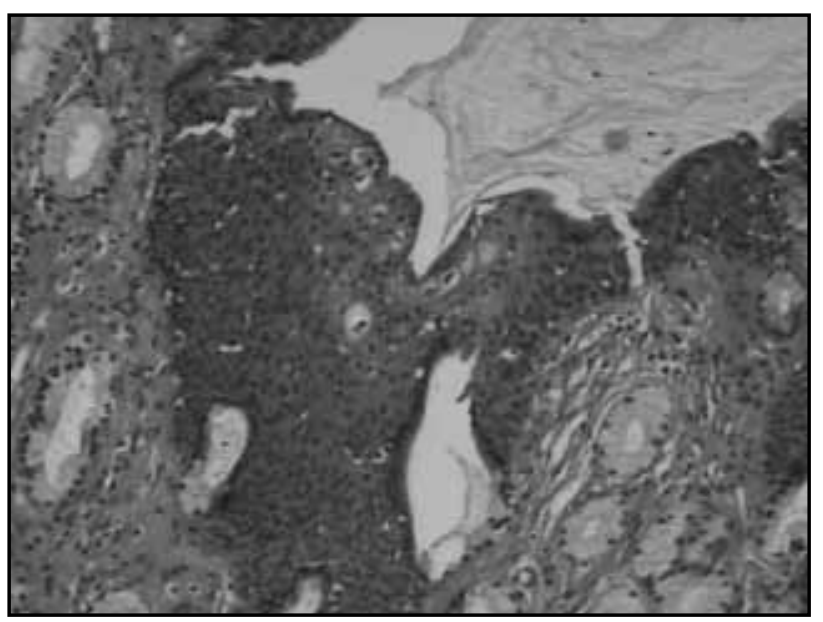

Figure 3 - Ductal epithelium lined by squamous metaplasia (HE, magnification 100x) $H E$ : hematoxylin and eosin.

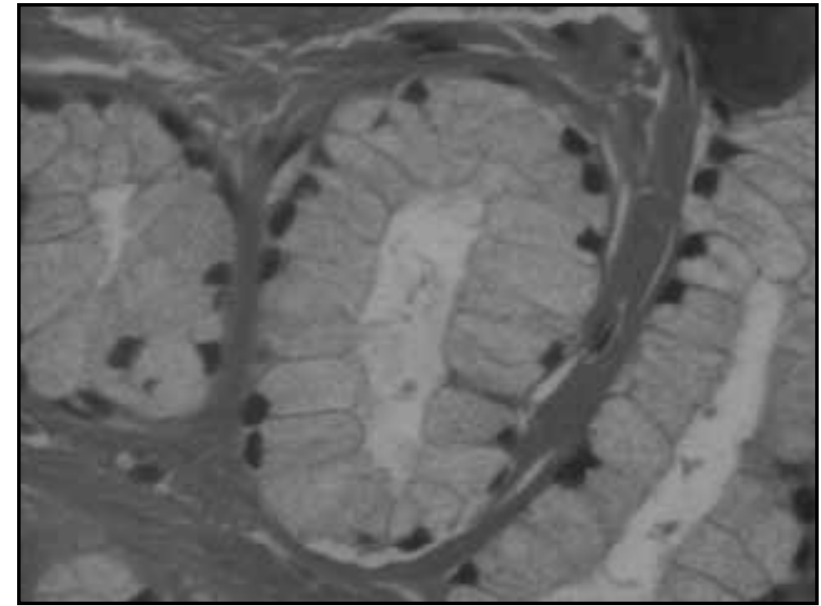

Figure 4 - Acinar cells' characteristic: clear cytoplasm and basal nucleum (HE, magnification 200x)

HE: hematoxylin and eosin.

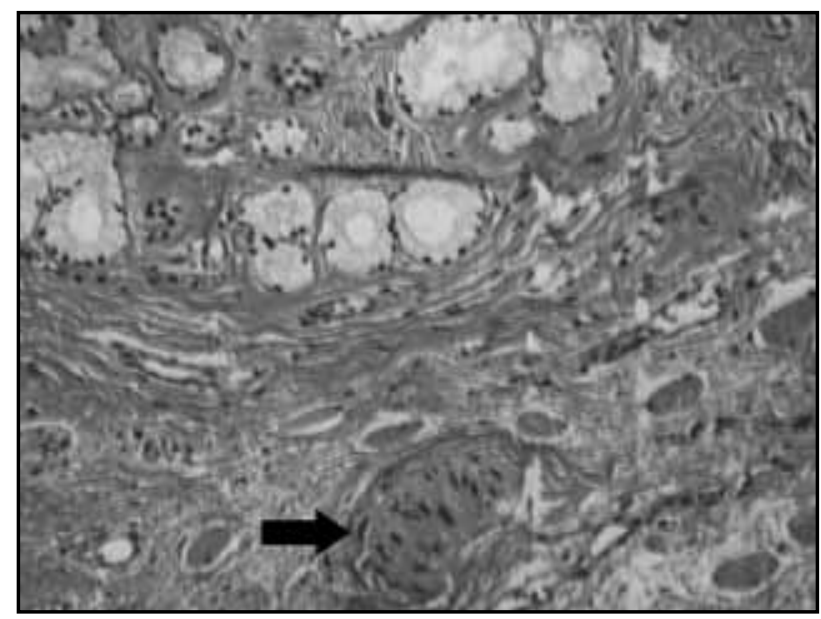

Figure 5 - Nerve fiber (marked) on lesion's periphery near muscle fibers and small blood vessels (HE, magnification 100x)

$H E$ : hematoxylin and eosin.

characteristics like architecture and margin are not mentioned in all descriptions, doubts remain of the true nature of these lesions. For example, Koenig and Tavassoli were "skeptical" about the diagnosis of the lesions described as adenomas by Honoré and $\mathrm{O}^{\prime} \mathrm{Hara}^{(4,7)}$.

Beyond that, no lesions diagnosed purely as adenoma were reported in BG after the mentioned criteria. In 2000, a hybrid carcinoma with two morphological patterns arising from an adenoma was described ${ }^{(10)}$. Three years later, an adenoma in the minor vestibular glands that accomplished the characteristics proposed by Koenig and Tavassoli was reported $^{(11)}$.

In our literature review, the average age of the patients is approximately 36 years-old. The youngest and the oldest patients reported with $\mathrm{NH}$ are 19 year-old and 56 year-old, respectively ${ }^{(7)}$. The age group appears to be different from 
the BG's carcinomas. According to the literature reviewed by Leuchter et al., the carcinoma's incidence peak is on the post-menopause, but one third of the BG's carcinomas were reported in patients whose age are below the fifth decade ${ }^{(8)}$.

Our first case's bilaterality stands out. Only three cases are bilateral in our review. Another characteristic to be mentioned from our first case is the previous history of recurrent BG's abscess. Santos et al. briefly reported one case of a 26 year-old patient that clinically presented as a "recurring Bartholin cyst" and another case of a 37 year-old presented as "recurrent vulvar lump"(13). Honoré and O'Hara also described one patient that presented previous $\mathrm{BC}$ duct cysts, but they diagnosed this lesion as an adenoma ${ }^{(4)}$. Inflammatory or infectious process can induce hyperplasia due to chronic cellular lesion mechanism ${ }^{(12)}$.

Surgical intervention and local trauma can also act as etiological factors to glandular proliferation, as it was reported on the minor vestibular glands ${ }^{(2)}$. Hyperplasia can also be resulted from hormonal milieu alteration ${ }^{(12)}$. To our knowledge, no author found a causal nexus between BG's hyperplasia and hormonal stimulation. However, Argenta et al. reported one case of bilateral hyperplasia, whose patient was receiving a daily estrogen and progesterone hormone replacement therapy for nine months ${ }^{(1)}$. Despite this etiology cannot be confirmed in this case, evidently, it cannot also be excluded.

Although none of our cases showed concomitance between duct cysts and $\mathrm{NH}$, this association appears to be reasonably frequent. From the reviewed cases whose diagnosis was $\mathrm{NH}$, seven have this association ${ }^{(3,7,13)}$. One fair interpretation for this finding is that compressive processes over the duct can lead to secretion stasis and duct cyst formation. This secretion congestion can also facilitate vaginal and vulvar microorganisms colonization. As previously said, infection causing chronic cellular injury can induce hyperplasic processes ${ }^{(12)}$.

Concerning early symptoms, there are a clear contrast between our first and our last two cases. Case 1 patient complained of dyspareunia and pelvic pain; case 2 tumor was discovered accidentally on a medical procedure and case 3 had a painless vulvar swelling.

Eighteen patients, more than half of the cases of our $\mathrm{NH}$ literature review, had brief symptomatology description. All these cases were obtained through medical records and they have early symptoms defined as "signs and symptoms of BG duct cyst" $\left.{ }^{\prime \prime}, 13\right)$. This term can just indicate the presence of vulvar swelling, but, it can also mean local discomfort, local pain, or, even dyspareunia.
The complaint of dyspareunia of our first patient can be explained by the hypothesis of nervous compression proposed by Madsanger and Young. The periphery of the specimen described by these authors presented tortuous blood vessels surrounding nerves. They proposed that vascular engorgement entrapping peripheral nerves against solid tumors of BG can cause pain ${ }^{(9)}$. We found non-tortuous small blood vessels accompanying nerves on our cases. To our point of view, these nerves can be compressed by other mechanisms like glandular tumor compressing nerves against the compartment of the perineum and sexual intercourse compression, causing dyspareunia.

Microscopically, our three cases are compatible with Koenig and Tavassoli's criteria for $\mathrm{NH}^{(7)}$. Maintained ductal/ acinar relationship is crucial for differential diagnosis and is well presented in our three cases.

There is neither mention of malignization of $\mathrm{NH}$ nor proof that this adaptation can lead to a greater risk for malignancy. However, the cases reporting malignization of adenomas alert doctors of the consequences of tumor's misdiagnosis ${ }^{(7,10)}$. Besides, delayed diagnosis due to incorrect clinical suspicion of BG duct cyst is frequently cited on literature ${ }^{(8)}$. This delay, in the worst case, can lead to the appearance of adjacent tissue invasion and metastasis, affecting patient's prognosis negatively.

Although malignant lesions are more common in postmenopausal women, the frequency in younger women is not irrelevant ${ }^{(8)}$. So, as Argenta et al., we admit that it may be prudent to follow the recommendation of Visco and Del Priori of incision with drainage and biopsy as the initial step in the evaluation of enlarged BGs $s^{(1,15)}$. This management leads to fewer complications in postmenopausal patients whose symptomatology does not justify complete excision as simple cysts and it also diminishes the incorrect or delayed diagnosis of malignant lesions in younger women ${ }^{(15)}$.

After diagnosing $\mathrm{NH}$, excision should be considered if there is any symptomatology negatively affecting patient's quality of life. Tesserra et al. mentioned that recurrent infections, pain and discomfort during the sexual intercourse are indications for excision ${ }^{(14)}$. We remind that, besides these indications, even vulvar aesthetic should be considered. Disturbed aesthetic may reduce patient's self-esteem and it may bring insecurity during sexual intercourse. The risk of tumor growth causing ductal compression and consequent $B G$ duct cyst should also be considered. To our knowledge, there aren't long term follow-up of non-symptomatic patients, whose $\mathrm{NH}$ underwent conservative treatment instead of complete excision. 


\section{References}

1. ARgENTA, P. A. et al. Bartholin's gland hyperplasia in a postmenopausal woman. Obstet Gynecol, v. 90, n. 4, pt. 2, p. 695-7, 1997.

2. AXE, S. et al. Adenoma in minor vestibular glands. Obstet Gynecol, v. 68, n. 1, p. 16-8, 1986.

3. BEN-HAROSH, S.; COHEN, I.; BORNSTEIN, J. Bartholin's gland hyperplasia in a young woman. Gynecol Obstet Invest, v. 65, n. 1, p. 18-20, 2008.

4. HONORÉ, L.; O'HARA, K. E. Adenoma of the Bartholin gland: report of three cases. Europ J Obstet Gynec Reprod Biol, v. 8, n. 6, p. 335-40, 1978.

5. HYUN-SOO, K. et al. Bilateral Bartholin's gland hyperplasia associated with Bartholin's gland cyst: a brief case report. Korean J Pathol, v. 42, p. 314-6, 2008.

6. KAZAKOV, D. et al. Nodular hyperplasia of the Bartholin gland: a clinicopathological study of two cases, including detection of clonality by HUMARA. Am J Dermatopathol, v. 29, n. 4, p. 385-7, 2007.

7. KOENIG, C.; TAVASSOLI, F. A. Nodular hyperplasia, adenoma, and adenomyoma of Bartholin's gland. Int $\mathrm{J}$ Gynecol Pathol, v. 17, p. 289-94, 1998.

8. LEUCHTER, R. S. et al. Primary carcinoma of the Bartholin gland: a report of 14 cases and review of the literature. Obstet Gynecol, v. 60, n. 3, p. 361-8, 1982.
9. MANDSAGER, N. T.; YOUNG, T. W. Pain during sexual response due to bilateral Bartholins gland adenomas. A case report. J Reprod Med, v. 37, n. 12, p. 983-5, 1992.

10. PADMANABHAN, V.; COOPER, K. Concomitant adenoma and hybrid carcinoma of salivary gland type arising Bartholin's gland. Int J Gynecol Pathol, v. 19, p. 377-80, 2000.

11. PUNIA, R. P. et al. Minor vestibular gland adenoma: a case report. Aust N Z J Obstet Gynaecol, v. 43, p. 322-3, 2003.

12. RUBIN, E.; GORSTEIN, F. Patologia: bases clinicopatológicas da medicina. 4. ed. Rio de Janeiro: Guanabara Koogan, 2006. v. 7-8.

13. SANTOS, L. D.; KENNERSON, A. R.; KILLINGSWORT, M. C. Nodular hyperplasia of Bartholin's gland. Pathology, v. 38, n. 3, p. 223-8, 2006.

14. TESSERRA, F. et al. Nodular hyperplasia of the Bartholin gland increasing in size during sexual intercourse. J Low Genit Tract Dis, v. 4, n. 1, p. 18-20, 2000.

15. VISCO, A. G.; DEL PRIORE, G. Postmenopausal Bartholin's gland enlargement: a hospital-based cancer risk assessment. Obstet Gynecol, v. 87, p. 286-90, 1996. 